\title{
Studies On Some Technological Factors Affecting Some Veterinary Drug Residues In Buffalo's Milk
}

\author{
S.A. El-Behairy*; U.M. Radwan**; El-Nawawy, M.A.***; and \\ Mona A.H. Mohamed* \\ * Food Evaluation and Food Sci. Dept., National Organization for Drug Control and \\ Research (NODCAR), Giza, Egypt. \\ ** Agric. Dept., Inst. Of Environmental Studies and Research, Ain Shams Univ, \\ *** Food Sci. Dept., Fac. of Agric., Ain Shams Univ.
}

\begin{abstract}
In the present study a suggested rapid method for detection of some veterinary drug residues namely ciprofloxacin, ivermectin and triclabendazole in milk and studied the effect of some technological factors on the residues of such drugs in buffalo's milk. The suggested method depends on the extraction of previously mentioned drugs by dialysis through a membrane in suitable solvent, then measuring the absorbance spectrophotometrically at 278 , 243 and 307 n.m. respectively.

Ciprofloxacin is bounded to milk while ivermectin and triclabendazole are completely dissolved in the cream layer.

Data indicated that these drugs showed high thermal, salt concentration up to $20 \%$ and $\mathrm{pH}$ stability. Therefore these veterinary drugs can be a hazard source in milk retentate, concentrated milk, cheese or other concentrated milk protein products (Entriquez, 2000). Thus application of HACCP system in milk production and processing must be taken into consideration to ensure a safe product for the consumer.
\end{abstract}

\section{Introduction}

Veterinary drug residues in milk and milk products are one of the important hazard sources, which can lead to risk for the human health. The risk of these residues is not of acute toxicity but it can cause chronic toxicity due to the cumulative effect (Brumanagh, 2003 and Woodward 2005). The toxicity can cause allergic disease or organic disease or in some cases cancer (Galer and Monro 1998). The lacteal excretion of most veterinary drugs is governed by simple, passive diffusion. Only few drugs are known to undergo active transport. Not less than 18 factors that affect the rate and the extent of drug excretion into milk and subsequent consumption have been identified (Rossi and Scottwright, 1997). These factors fall into six general areas: (1) The pharmacology of the drug in the animal, (2) The physiology of the udder, (3) The milk composition, (4) The nutritional demands and pharmacology of the consumer, (5) The physical-chemical properties of the drug in the matrix, (6) The effect of the technological processes. Three of the most important biopharmaceutical factors that influence lacteal drug excretion are protein binding, ion trapping and lipid solubility (Aniello et al., 2002).

In veterinary practice Quinolones group (ciprofloxacin), anthelminthic group (ivermectin) and benzimidazole group (triclabendozole) have been recommended for the treatment of several infections.

As for ciprofloxacin, it is a major metabolite of enrofloxacin, and is widely used in human medicine. Enrofloxacin and ciprofloxacin are the second generation of fluoroquinolone with a broad spectrum of antibacterial activity. Enrofloxacin is administered in veterinary medicine by 
subcutaneous injection or orally to cattle and buffalo's for the treatment of mastitis, respiratory and alimentary tract (Hemandez et al., 2000). The recommended dose is 2.5 to $5 \mathrm{mg}$ enrofloxacin $/ \mathrm{kg}$ body weight/day for 3 to 5 days. The toxilogical ADI of ciprofloxacin or enrofloxacin is $30 \mu \mathrm{g} / \mathrm{kg}$ body weight calculated by applying a safety factor of 100 to the NOEL of $3 \mathrm{mg} / \mathrm{kg}$ body weight/day of a dietary 90 day repeated dose study (Boutsoglou and Fletouris, 2001). There were few data on the effect of the technological processes on the behaviour of veterinary drug residues.

On the other hand, ivermectins (IVM) macrocylic lactone class of endectocide and anthelmintic, insecticidal and acaricidal compounds which by increasing the membrane permeability to chloride ions mediate the paralysis of the nematodes and certain class of ectoparasites of food producing animals (European Medicines Agency Vet. Medicinal and Inspections, 2004). This drug accounts for its long resistance in plasma and excretion with milk (Aniello et al., 2002). The drug is administrated by $200 \mu \mathrm{g} / \mathrm{kg}$ body weight. The MRL value for ivermectin $(10 \mu \mathrm{g} / \mathrm{kg})$ in cows milk was determined by the joint of FAO/WHO group. Committee on Food Additives (JECFA, 2000).

Concerning triclabendazole (TCBZ), it is a potent member of benzimidazole group of anthelmintic agent and used for the control of liver fluke infection and tapeworms in domestic animals. TCBZ and its metabolites are antihelmintically active. TCBZ is very rapidly absorbed and completely oxidized to sulfoxide and sulfone metabolites in sheep, goats and cattle. TCBZ sulfoxide reaches peak concentrations 30-32 h after administration. Both metabolites bind strongly to plasma proteins; particularly albumin. Metabolites are excreted via the bile. More than $90 \%$ of the total dose is excreted in the feces, $2 \%$ in urine and less than $1 \%$ in milk.

Therefore, determination of ciprofloxacin, ivermectin and triclabendazole (TCBZ) residues in buffalo's milk by simple method and the effect of some technological factors on the behaviour of these residues in milk are tasks in this work.

\section{Material And Methods}

\section{Material:}

Antibiotic free buffalo's milk from healthy dairy animals were purchased from the Dairy Det. Fac. of Agric., Cairo Univ., Giza. The milk composition was $7 \%$ fat and 9.5\% S.N.F. Ciprofloxacin hydrochloride, ivermectin and triclabendazole were kindly supplied by Chemo, SA., Lugano, Switzerland, Forehigh Trade and Industry Co., Ltd. Hebei and Jenssen Pharma, Belgium respectively.

\section{Methods:}

Preparation of milk with ciprofloxacin, ivermectin and triclabendazole :

Ciprofloxacin, ivermectin and triclabendazole in powder form were added to buffalo's milk separately in concentration of $100,10,10 \mu \mathrm{g} / \mathrm{l}$ at $35^{\circ} \mathrm{C}$ and incubated for $4 \mathrm{hr}$ as equilibrium time. All experiments for ciprofloxacin were done using skimmed milk as a control for buffalo's milk. For invermectin and triclabendazole all experiments were done using the cream derived from buffalo's milk.

\section{The effect of some technological factors on the residues of ciprofloxacin, ivermectin and triclabendazole in buffalo's milk: \\ The effect of sodium chloride} concentration, $\mathrm{pH}$ and temperature were studied. Sodium chloride was added to milk in different concentration $(2,4,6,8,10,15$ and $20 \%$ ) in the presence of aforementioned drug concentrations.

The milk salt mixtures were dialyzed against the same concentration of salt solution and the drug residues were determined spectrophoto-metrcically at 276, 243 and $307 \mathrm{~nm}$ for ciprofloxacin, ivermectin and triclabendazole in the dialyzate water acetonitrile and DMSO respectively.

The same experiment was done for the three mentioned drug residues to study 
the effect of $\mathrm{pH}$ using milk acidified to $\mathrm{pH}$ 4.6, 5.0, 5.5, 6.0 and 6.5 in concentrations $3.3,10$ and $10 \mathrm{ug} / \mathrm{lit}$. for ciprofloxacin, ivermectin and triclabendazole respectively. After equilibrium time the milk mixtures were dialyzed against the same $\mathrm{pH}$.

The effect of temperature was done using the drugs understudy incorporated with milk and heated to $65^{\circ} \mathrm{C} / 30 \mathrm{~min}$, $75^{\circ} \mathrm{C} / 15 \mathrm{sec}, 80^{\circ} \mathrm{C} / 5 \mathrm{~min}$ and $100^{\circ} \mathrm{C} / 5 \mathrm{~min}$. The heated milk was cooled and then dialyzed against the suitable solvents. The same experiment was done with milk in different fat percentage $(0.5,1.5,3$ and $6 \%)$.

Ciprofloxacin, ivermectin and triclabendazole extraction:

Ciprofloxacin was added to buffalo's milk, equilibrated then mixed with the extraction solution (dichloromethane: phosphate buffer $\mathrm{pH} 7.0,0.1 \mathrm{M}(3: 1)$. (Anadon, et al., 2001). The ciprofloxacin was extracted 3 times and the collected solution was concentrated then dialyzed against dichloromethane. The dialysate was determined spectrophotomet-rically at 276 $\mathrm{nm}$ and with HPLC. The extraction of ivermectin and triclabendazole was done 3 times by using acetonitrile and Dimethyle sulfoxide (DMSO) respectively. The collected solutions were concentrated by the same way as mentioned before and determined at 243 and $307 \mathrm{~nm}$ respectively. Confirmatory experiments were done by HPLC.

The obtained residues were performed by HPLC (Perkin Elemer system Quaternary pum). For ciprofloxacin, variable wave length detector operated at $277 \mathrm{~nm}$ was used and data station software turbochrome with Rheodyne injector of 20 ul-loop were analyzed. The analytical separation was achieved on Lichrosphere RP18 (125 x $5 \mathrm{~mm}$ ID). The mobile phase was $0.02 \mathrm{M}$ phosphate buffer $\mathrm{pH}$ 2.5/methanol $(85 / 15 \mathrm{v} / \mathrm{v})$.

Concerning ivermectin phenomenon C18 (5 micron, $250 \mathrm{~mm} \mathrm{X} 4.6 \mathrm{~mm}$ ) with the same type $\mathrm{f}$ guard column. Mobile phase consisted of methanol and water in a ratio of $90: 10(\mathrm{v} / \mathrm{v})$ and the flow rate was $1.0 \mathrm{ml} / \mathrm{min}$. The detection wavelength was $243 \mathrm{~nm}$.

In case of triclabendazole the residues were separated on a Capcell Pak C18 UG
120 (5 micron, 150 X 4.6 mm I.D. column and determined by UV detection at $307 \mathrm{~nm}$. The mobile phase was acetonitrile $0.05 \mathrm{M}$ ammonium acetate $(50: 50)$, and the flow rate was $0.8 \mathrm{ml} / \mathrm{min}$ at $40^{\circ} \mathrm{C}$. The sample concentration was calculated for the three drugs by the following equation:

$\underline{\text { Standard concentration } \mathrm{x} \text { Peak area of sample }}$ Peak area of standard

\section{Results And Discussion}

Extraction and detection of ciprofloxacin, ivermectin and triclabendazole in buffalo's milk:

The idea in this work was to find a simple method to extract the residues of the veterinary drug from buffalo's milk with cheap and accurate method. In the prexperiments we have found that ciprofloxacin was not bound with fat, in the meantime and on the contrary, ivermectin and triclabendazole were bounded with buffalo's milk cream layer. Therefore, all experiments for ciprofloxacin was done with skim milk as a control, and sample preparation used liquidliquid extraction. Thus ciprofloxacin was extracted with using dialysis technique and determined in the dialysate spectrophotometrically at $278 \mathrm{~nm}$ and HPLC determination was used as confirmatory method (Cinquina et al., 2003). Results in Fig. (1) shows that the time required to detect the residual concentration of ciprofloxacin was 3 hours.

Bayo et al., (1994) found that the extraction of chloramphinicol from milk required $5 \mathrm{~h}$. The mean recoveries of their method was $99 \%$ and the limit of quantification was $10 \mu \mathrm{g} / \mathrm{l}$ milk.

Our method was successfully applied for the first time in buffalo's milk and can be suitable for the quantification of ciprofloxacin for regulatory purposes by $100 \%$ recovery comparing with standard. While determination of the degree of drug-protein binding can be carried out using dialysis or ultrafiltration techniques (Boutsoglou and Fletouria, 2001), the milk drug mixtures were filled in the dialysis tube and dialysed against water. The drug was determined in the dialysate, Fig (2). The results showed 
that the drug was protein bounded while the passive transport was low. Different researchers (Aramayona et al., 1996, El Banna and Abou El-Sooud, 1988 and Malbe et al., 1996) found that the ciprofloxacin bounded to plasma serum protein.

Concerning ivermectin and triclabendazole, all experiments were done with cream layer of buffalo's milk owing to the completely dissolved of the two drugs in it, and samples preparations used liquid liquid extraction. As mentioned before the objective of the herein work was done to find a method for the extraction of ivermectin and triclabendazole distinguished with simplicity, cheap and accuracy. By the same way mentioned the dialysate of the two drugs were determined spectrophtometrically and HPLC was used as a confirmatory method.

For the extraction of ivermectin, it has one peak at $244 \mathrm{~nm}$. The suggested method achieved a percentage of drug recovery about $100 \%$ and reflect the completely dissolved of drug residues in buffalo's milk cream layer.

The same trend of results was noticed with triclabendazole extraction by same way mentioned before. It has one peak at $307 \mathrm{~nm}$, the recovery \% by using the suggested method was about $98-100 \%$ after 5 hrs (Equilibrium time).

For the confirmation of the resulting dialysate concerning with ivermectin and triclabendazole, HPLC quantitative method was performed according to Zhao et al., 2005 and Takeba et al., 2000 in this respect respectively. The results prove the efficiency of the conventional dialysis methods used for both drugs.

\section{Effect of some technological conditions on the residues of ciprofloxacin, ivermectin and triclabendazole in buffalo's milk. Sodium chloride concentrations:}

Sodium chloride used in different ratio in cheese or some other fermented milk. The ciprofloxacin was added to buffalo's milk in the presence of different sodium chloride ratios. Data in Fig. (3) show that the increase of the sodium chloride concentration increased the bounded drug residues and the release decreased. This can be due to the effect of the sodium chloride on the nature of the proteins (Chasten et al., 1994).

Concerning the effect of salt concentrations on the distribution of ivermectin residues the results are illustrated in Fig. (4). Data show that the salt concentrations 4 and $6 \%$ had no effect on the drug release, meanwhile $8,10,12,15$ and $20 \%$ had a slight effect on the release of drug ranged from $25-35 \%$ related to the control one.

Fig.(5) shows the effect of sodium salt concentrations on the release of triclabendazole. A slight decrease in the release of drug was noticed upon the concentration 2,4 and $6 \%$ salt, in the meantime no release of drug was noticed upon more than 6\% salt, i.e. $8,10,12,15$ and $20 \%$.

\section{Effect of pH:}

The increase or decrease in the milk $\mathrm{pH}$ can affect the drug characters. In the milk processing the $\mathrm{pH}$ is one of the key factors during the production of many dairy products. The data in Fig. (6) shows the effect of milk $\mathrm{pH}$ on the release of ciprofloxacin residues in filtrate. An increase of $\mathrm{pH}$ values 4.6, 5.5 and 6.6 was associated with a decrease of ciprofloxacin release \% 85, 80 and 50\% respectively.

Data concerning the effect of $\mathrm{pH}$ values up to 6.6 on ivermectin residues release show that no effect. On the contrary an increase in the \% of release for triclabendazole was noticed at $\mathrm{pH}$ values $5,5.5$ and 6.0 by $26,21.7$ and $10.8 \%$ respectively, and no release of drug at $\mathrm{pH} 4.6$ and 6.6. Fig. (7). The neglected effect of $\mathrm{pH}$ on IVM may be due to the less ionizable of drug structure (Nikolaos et al., 2001).

\section{Effect of temperature:}

Table (1) shows the effect of heat treatments on the release of ciprofloxacin residues in buffalo's milk. The obtained data revealed that the increase of heat treatments was associated with a decrease in $\%$ bound drug in comparison with control (raw milk) at a level of initial concentration $3.3 \mathrm{ug} / \mathrm{ml}$ by $16.6,21.9,16.6$ and $1.8 \%$ under the manipulation of $63^{\circ} \mathrm{C} / 30 \mathrm{~min}, 72^{\circ} \mathrm{C} / 15 \mathrm{sec}, 80^{\circ} \mathrm{C} / 15 \mathrm{~min}$ and $100^{\circ} \mathrm{C} / 15$ min respectively. 
Table (2) shows that gradual increase in the prementioned heat treatments were associated with an increase in the \% release of IVM residues by 16.6, 21.4, 47.6 and 69.0 respectively corresponding to the control (10 ug/lit).

\section{Effect of fat content:}

The fat content of milk varied from product to the other, therefore, the effect of the fat content of the buffalo's milk on the release of ciprofloxacin was studied. Data in Fig. (8) showed that the fat content had slight effect on the ciprofloxacin residue. Generally, it decrease with the increase of milk fat till $3.5 \%$ fat then decreased with the increase in the percentage of milk fat. This increase can be due to the increase of fat globule membrane in which the residual binded with the protein of the membrane.

Table (1) Effect of some heat treatments on the release of ciprofloxacin residues in buffalo's milk.

\begin{tabular}{|c|c|c|}
\hline Heat treatment & Release & Bound \% \\
\hline Control & 2.6 & 21.2 \\
\hline $63^{\circ} \mathrm{C} / 30 \mathrm{~min}$ & 2.75 & 16.6 \\
\hline $72^{\circ} \mathrm{C} / 15 \mathrm{sec}$. & 2.37 & 21.9 \\
\hline $80^{\circ} \mathrm{C} / 15 \mathrm{~min}$. & 2.75 & 16.6 \\
\hline $100^{\circ} \mathrm{C} / 15 \mathrm{~min}$. & 3.25 & 1.5 \\
\hline
\end{tabular}

Table (2) Effect of some heat treatments on the ivermectin residues in buffalo's milk.

\begin{tabular}{|c|c|c|}
\hline Heat treatments & $\begin{array}{c}\text { Release } \\
\text { (ug/lit) }\end{array}$ & $\begin{array}{c}\% \\
\text { Release }\end{array}$ \\
\hline Control (st. 0.42) & N.D. & N.D. \\
\hline $63^{\circ} \mathrm{C} / 30 \mathrm{~min}$ & 1.6 & 16.6 \\
\hline $72^{\circ} \mathrm{C} / 15 \mathrm{sec}$. & 2.1 & 21.4 \\
\hline $80^{\circ} \mathrm{C} / 15 \mathrm{~min}$. & 4.7 & 47.6 \\
\hline $100^{\circ} \mathrm{C} / 15 \mathrm{~min}$. & 6.9 & 69.0 \\
\hline
\end{tabular}

N.D. : Not detected. 


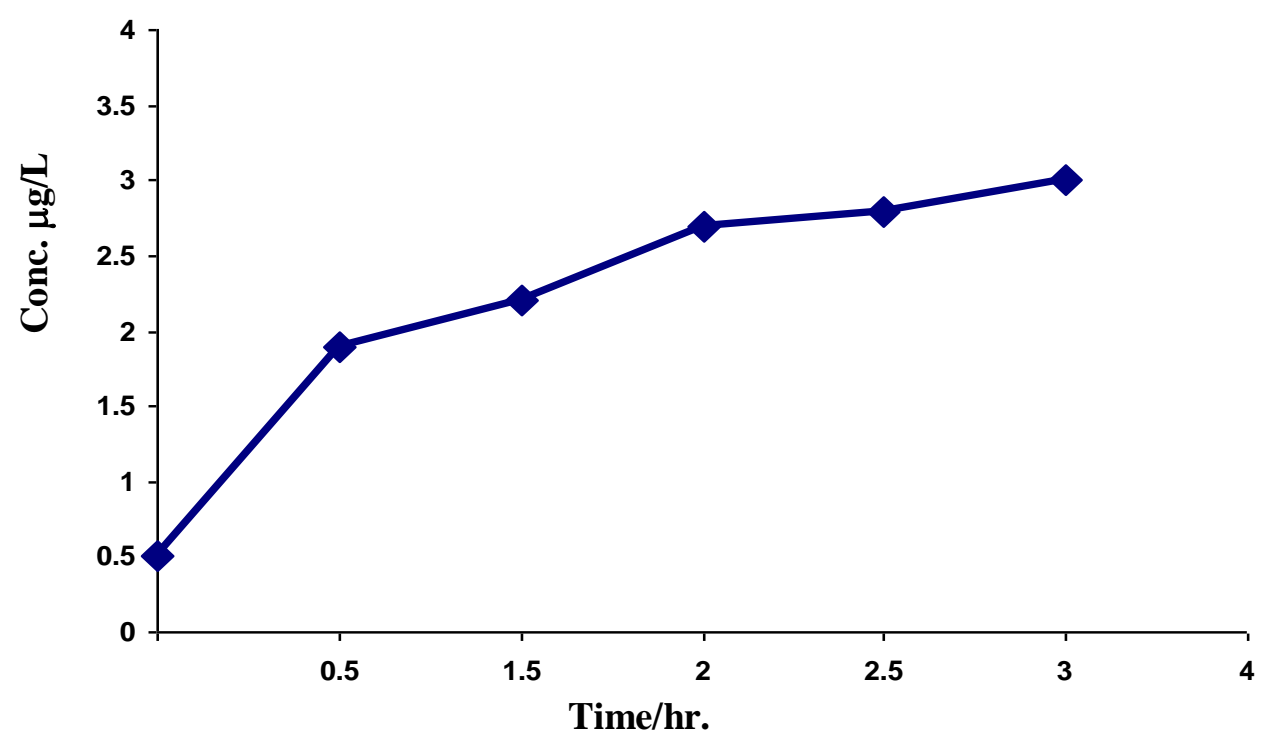

Fig (1) : Time required for ciprofloxacin extraction from buffaloe skim milk(initial concentration $3.3 \mu \mathrm{g} / \mathrm{L}$ ).

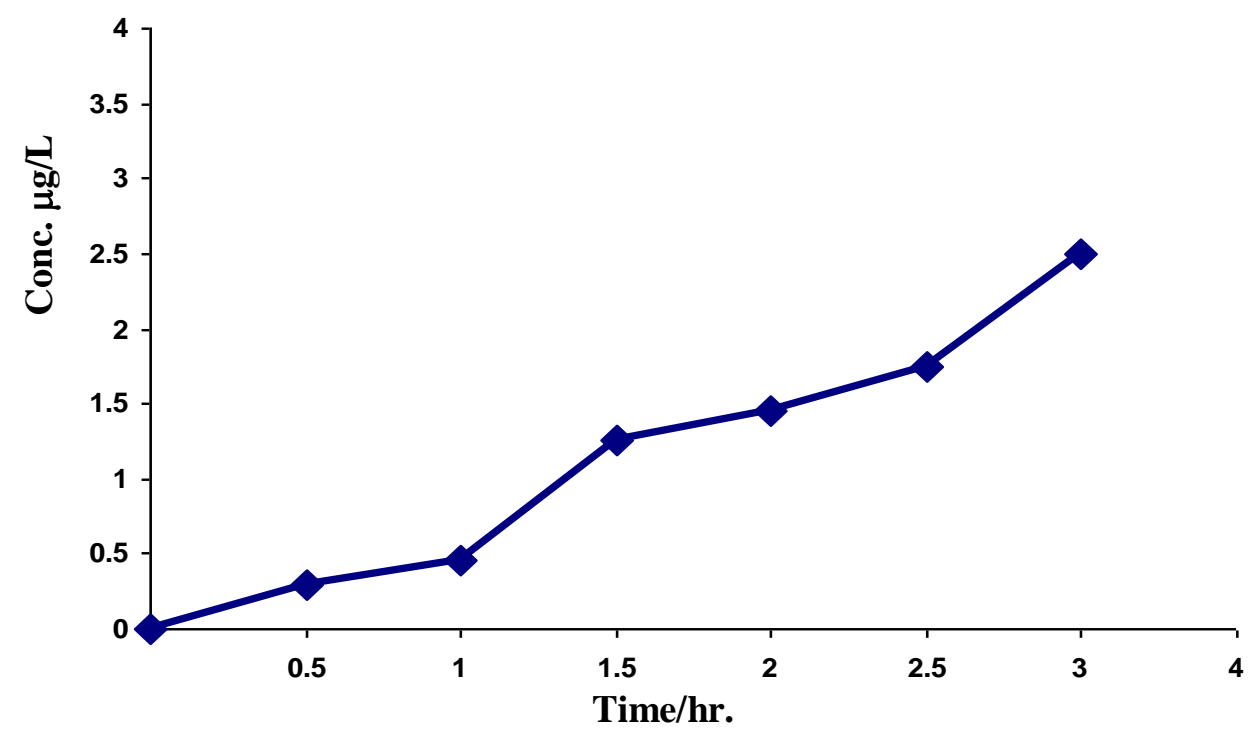

Fig (2) : Binding of ciprofloxacin residues on buffaloe milk protein (final concentration $3.3 \mu \mathrm{g} / \mathrm{L}$ ). 


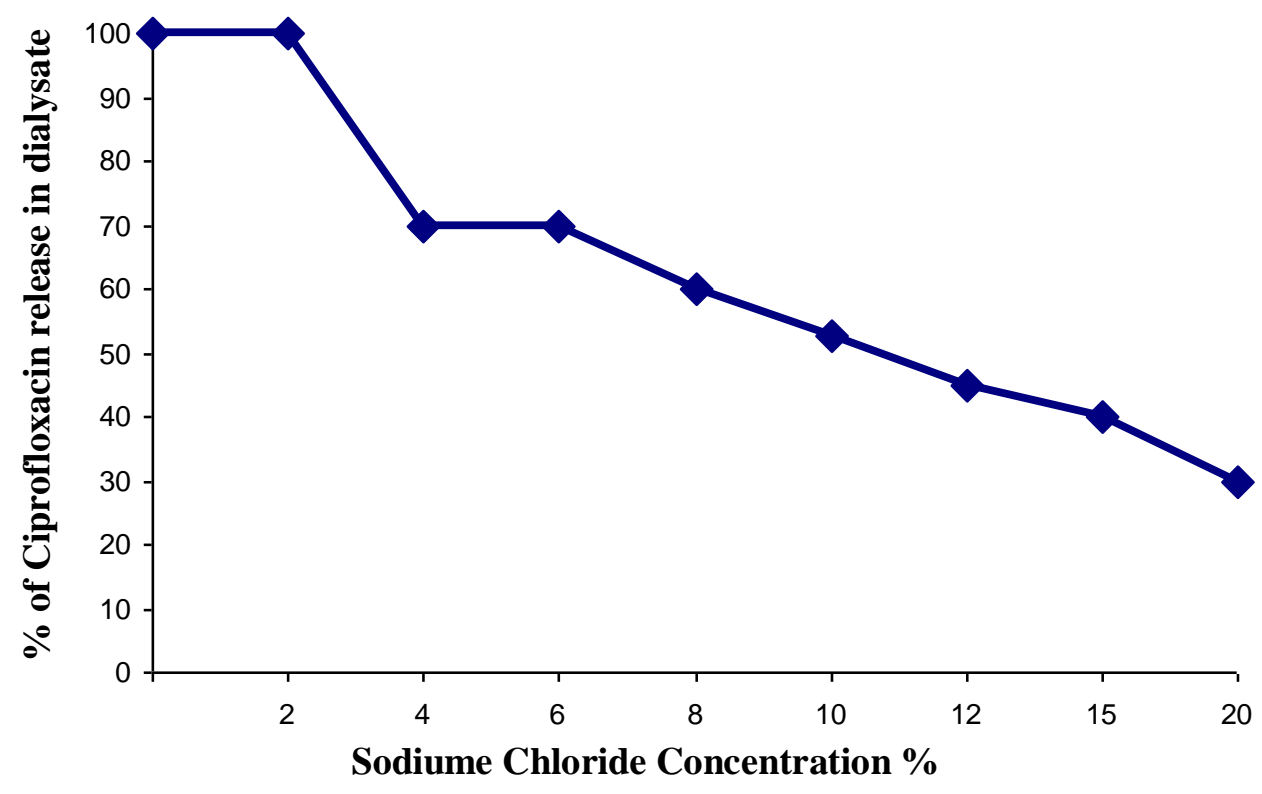

Fig (3) Effect of sodium chloride concentration on the binding of ciprofloxacin in milk.

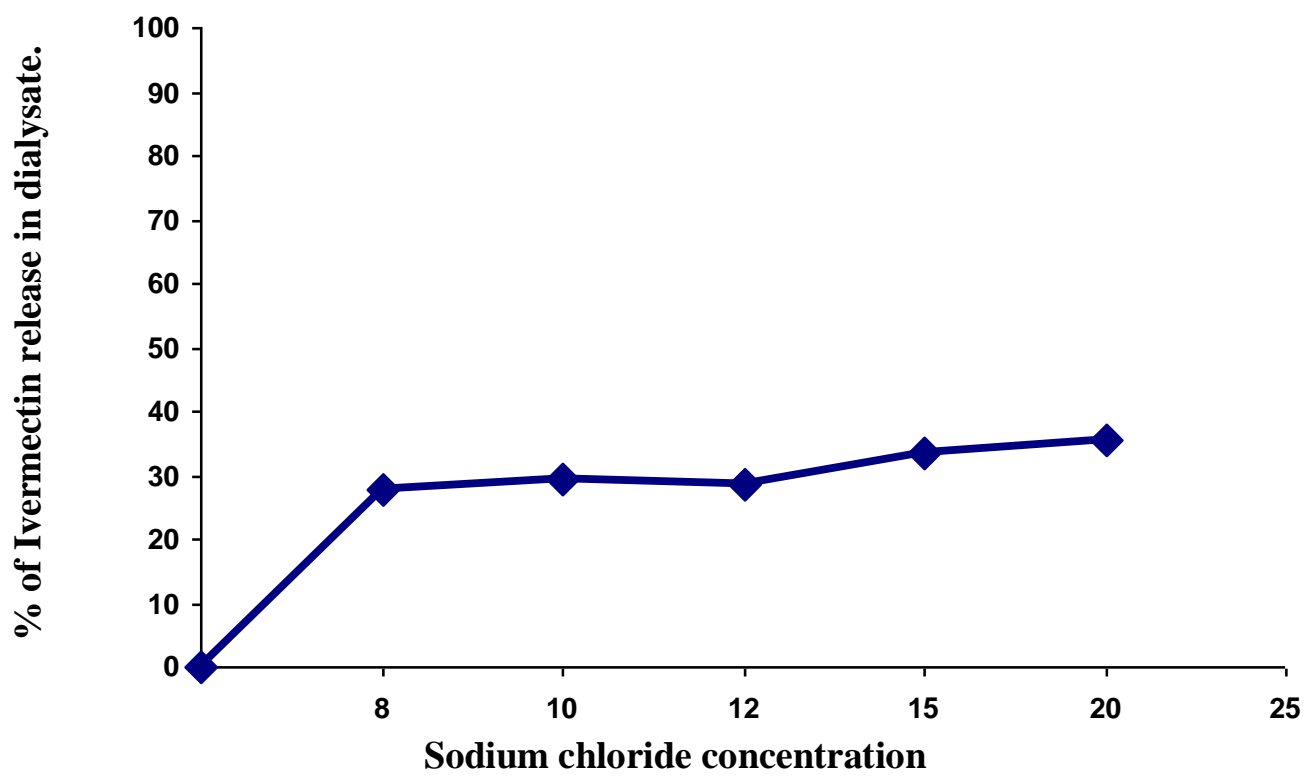

Fig (4) : Effect of Sodium chloride concentration on the binding of Invermectin in milk. 


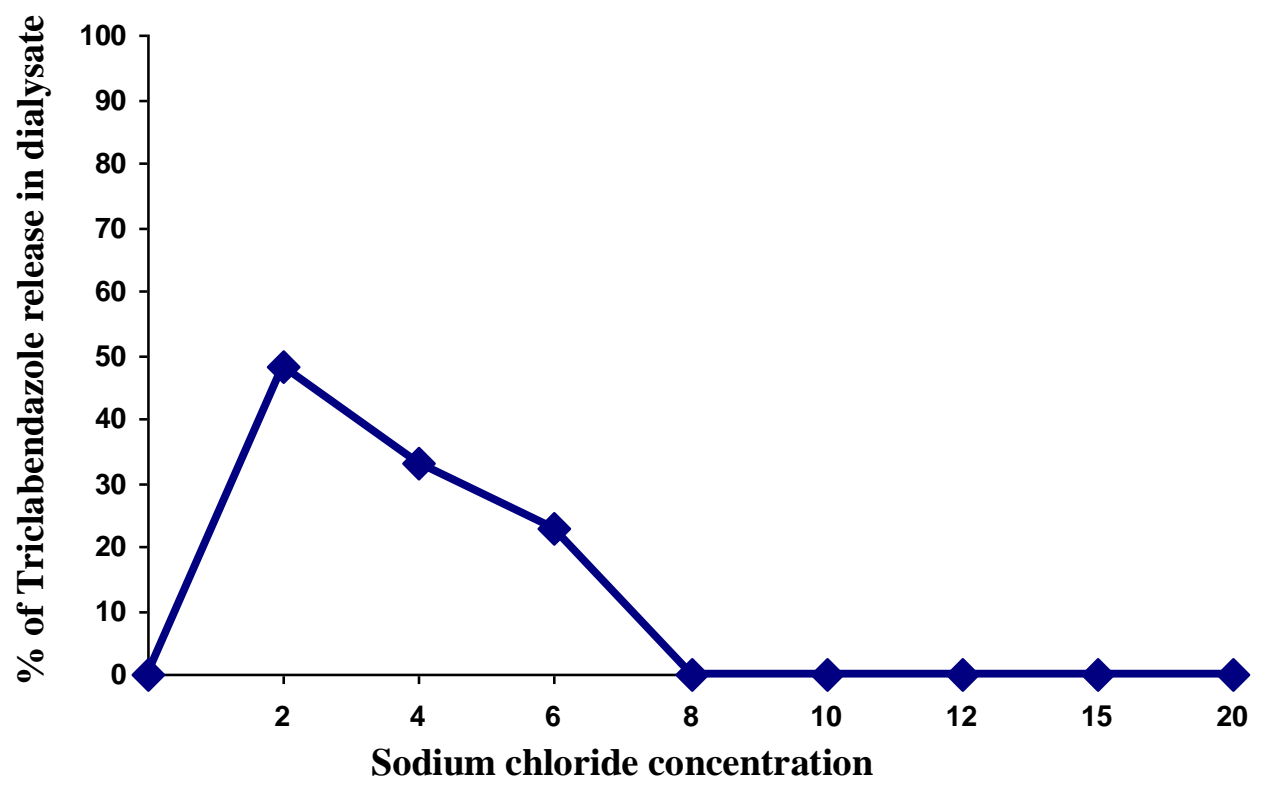

Fig (5) : Effect of sodium chloride concentration on the binding of Triclabendazole in milk.

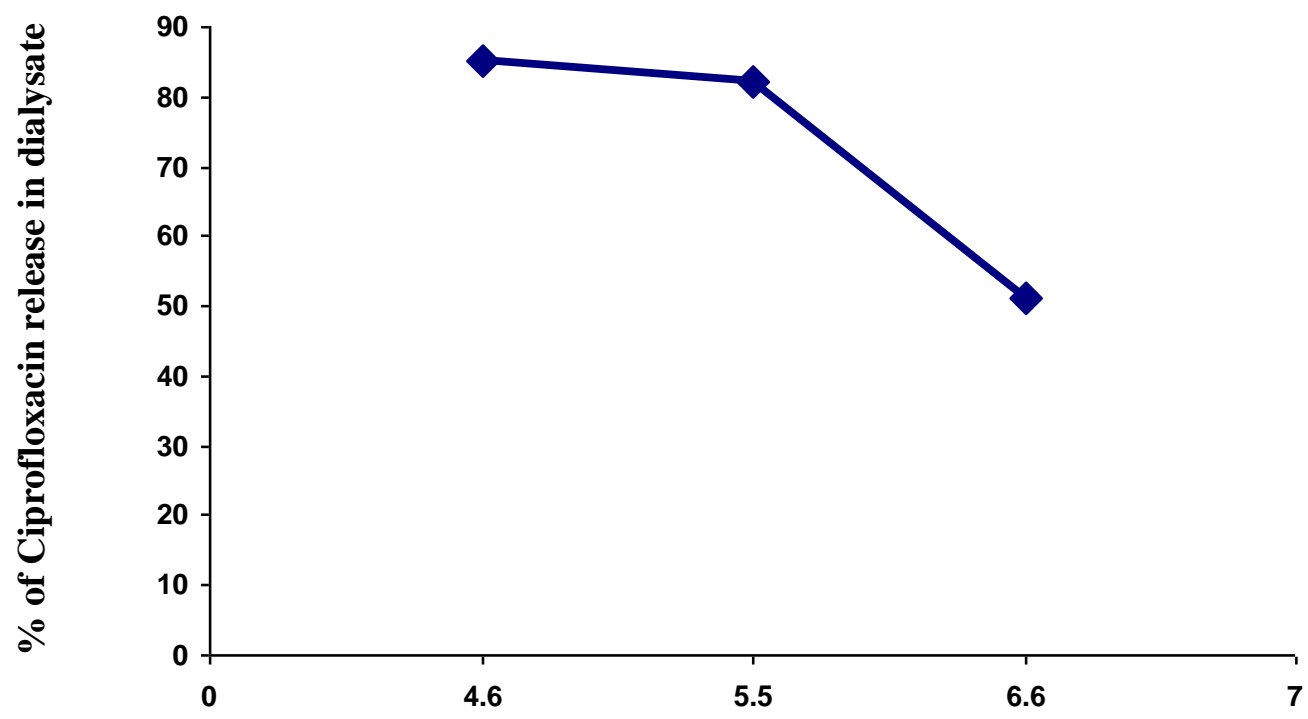

Milk pH

Fig (6): Effect of milk initial pH on ciprofloxacin release in dialysate. 


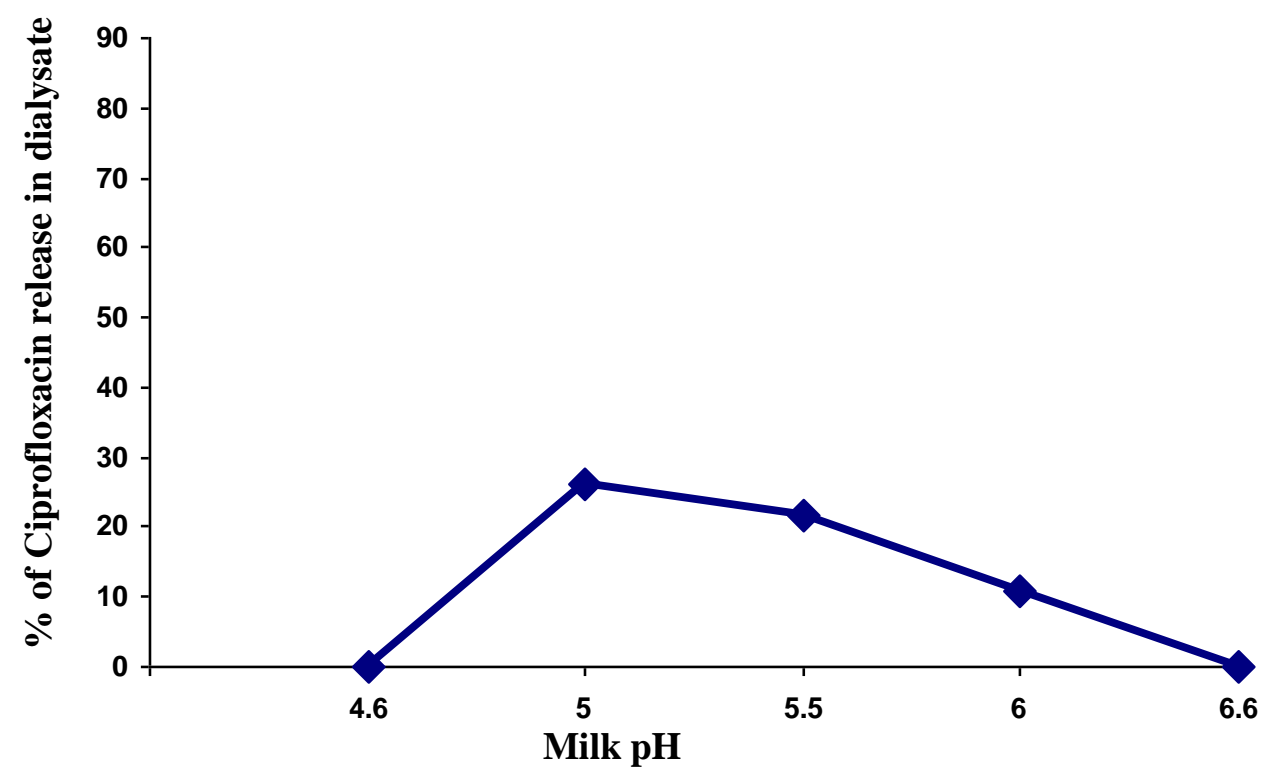

Fig (7): Effect of milk initial $\mathrm{pH}$ on the triclabendazole release in dialysate.

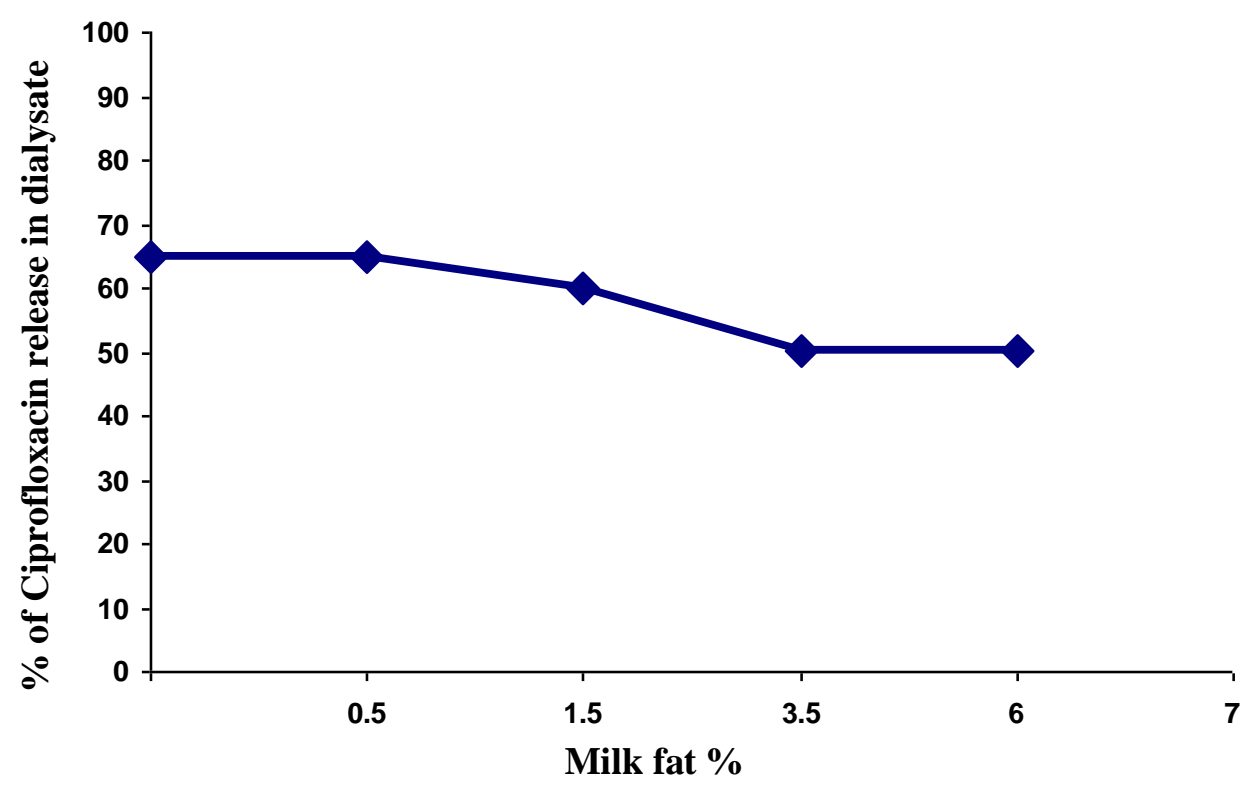

Fig (8) Effect of milk fat concentration on ciprofloxacin release in dialysate. 


\section{References}

1. Anadon, A.; Martinez, M.R.; Larranaga, Iturbe, J., Diaz, M.J., Frejo, M.T. and. (2001). Pharmacokin-etics and residues of ciprofloxacin and its metabolits in broiler chickens. Veterinary Science, 71, 101-109.

2. Aniello Anastasio, Mauro Esposite, Michele Amorena, Paolo Catellani, Luigi Serpe, and Maria Luisa Cortesi, (2002). Residues study of ivermectin in plasma, milk, and mozz-arella cheese following subcutaneous administration to buffalo's (Buballus bubalis). J. Agric. Food Chem., 50, 5241-5245.

3. Aramayona, J.J.; Mora, J., Fraile, L.J., Garcia, M.A.; Abadia, A.R. and Bregane, M.A. (1996): Penetration of enerofloxacin and ciprofloxacin into breast milk and pharmacokinetics of the drug in lactating rabbits and neonatal offspring.Am. J. Vet. Res. 57: $547-553$.

4. Bayo, J., Morno, M.A.; Prieta, J.; Diaz,S.; Saurez, J. and Domingues, L. (1994). Chloramphenicol extraction from Milk by using the di-phasic dialysis method followed by liquid chromatographic determination. J. AOAC Int. $77: 854$.

5. Boutsoglou, N.A. and Fletouris, D.J. (2001). Drug residues in food. Marcel Dekker, Inc, New York.

6. Brumbangh GW. (2003). How to respond to adverse drug reactions. Veterinary Clin. North AM. Food Anim. Pract. Nov., 19(3), 715-26

7. Chasteen ND, Grady JK, Wood Worth RC, and Mason AB (1994). Salt effecs on the physiological properties of transferrin. Adv. Exp. Med. Biol. 357 : 45-52. Dept. of Chemistry, University of New Hampshire, Durham 03824, USA..

8. Cinquina, AL, Roberti, P., Giannetti; L., Longo,F., Draisci, R., Fagiolo, A., and Brizioli, NR (2003). Determination of enrofloxacin and its metabolite ciprofloxacin in goat milk by high-performance liquid chromat-ography with diode-array detection. Optimization and validation. J. Chromatogr. A. 987 (1-2): 221-6.

9. El-Banna, H.A. and Aboel-Sooud, K. (1988). Kinetics of ciprofloxacin in lactating grates. Deutsche Tierarztl. Wschr 105: 35-38.
10. Enriquez, (2000). Residues of antibiotics and protection of the health of consumers. Notions of maximal residues limits and withdrawal time. Ann. Pharm. Fr. Dec; 58 (6 suppl) 455-63.

11. Galler DM and Monro AM (1988). Veterinary drugs no longer need testing for carcinogenicity in rodent bioassay. Regul. Toxicol Pharmacol. Oct., 28 (2) : 115-23.

12. Hemandez Arteseros JA, Compano R, Ferrer $R$ and Part Med (2000). Application of principal component regression to luminescence data for the screening of ciprofloxacin and enrofloxacin in animal tissues. Analyst. Jun; 125 (6) : 1155-8.

13. JECFA. Joint FAO/Epert Committee onFood Additives 44 the Meeing, Feb. 1524, 2000.

14. Malbe, M.; Salonen, M.; Fang, W. Oopik, T., Jalaks, M., Kiassen, $M$ and Sandholm, M. (1996). Disposition of enerofloxacin (Baytril@) into the udder after intravenous and infraarterial injections into dairy cows. J. Vet. Med. A. $43: 377$ 380 .

15. Nikolaos A., Botsoglou and Dimitrios J. Fletouris (2001). Drug residues in Foods. Aristotle University Thessaloniki, Greece. New York, Basel. Marcel Dekker Inc.

16. Rossi, T.D. and Scott Wright, D. (1997): Analytical considerations for trace determinations of drug in breast milk. J. Pharmaceut. Biomed. Anal. 15 : 495-504.

17. Tekeba, Fujinuma, K., Sakamoto, Miyazaki, T., Oka, H., Iton, Y. and Nakazawa, H., (200). Simultaneous determination of triclabendazole and its sulphoxide and sulphone metabolite in bovine milk by high-performance liquid chromatography. J.Chromator. A., June 16; 882 (1-2): 99-107.

18. Woodward KN (2005). Adverse reactions in human to veterinary medicinal products. J. Vet. Pharmacol. Ther. April, 28 (2), 185201.

19. Zhazo JH, Sun CJ, Mao LS, Yin ZN, Jiang B, Li Yx, (2005). Determination of ivermectin in pig serum by high performance liquid chromatography. Sichuan Da Xue Xue Bao Yi Xue Ban. Jan; 36(1): 1301,150 . 
دراسات على بعض العوامل التكنولوجية التي تؤثر على متبقيات بعض الأدوية النية البيطرية في اللبن الجاموسي

1سامي البحيري ، 2أسامة رضوان ، 3حمد النواوي ، ، 1منى عبد الفتاح حسن محمد

1 شعبة التقييم الغذائي و علوم الأغذية ـ الهيئة القومية للرقابة و البحوث الدوائيةـ.

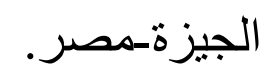

2 قسم العلوم الزر اعية ـ معهد الدراسات و البحوث البيئية - جامعة عين شمس. 3ق قسم علوم الأغذية ـ كلية الزراعة - جامعة عين شمس.

في هذه الدراسة تم استحداث طريقة سريعة للكثيف عن بعض الأدوية البيطرية

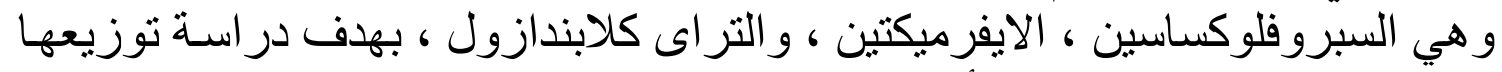

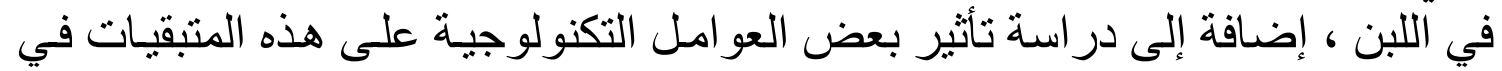

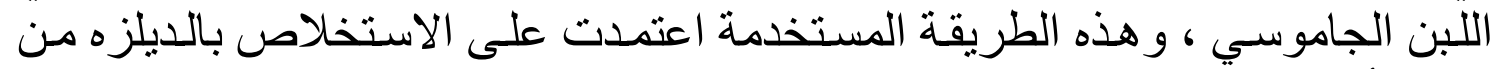

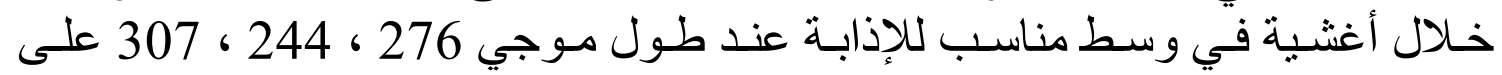

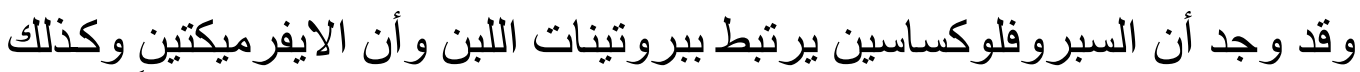

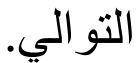

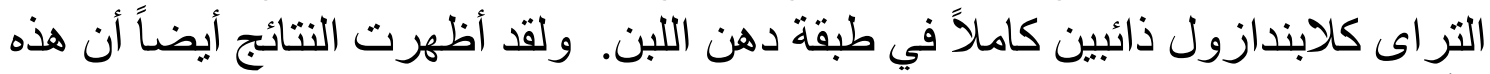

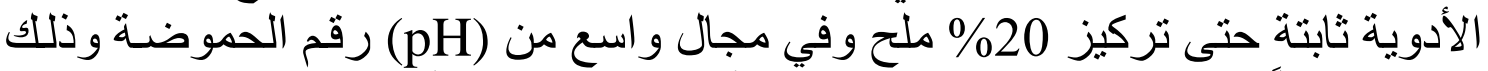

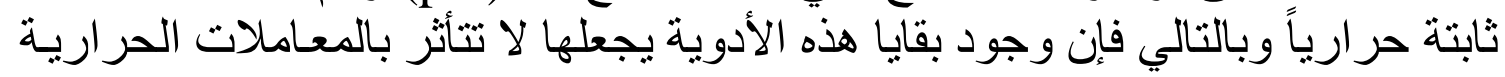

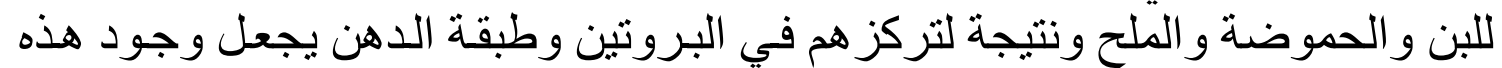

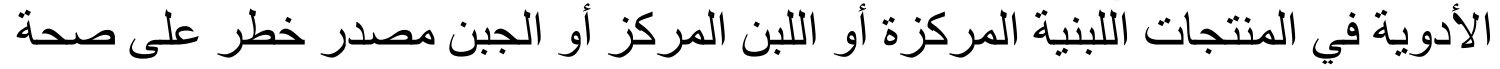

لذلك تتصح هذه الدر اسة بتتبع هذا الدواء خلال انتاج وتصنيع الألبان ومنتجاتها

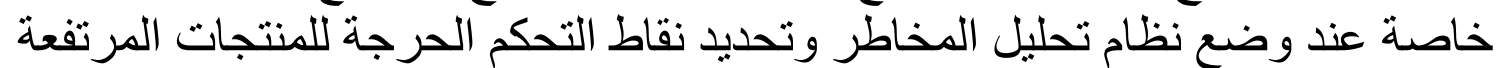

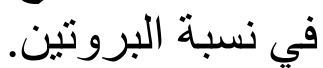

